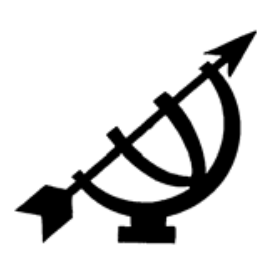

\title{
Nuwe wyn in ou sakke? Hoe die morele grondslag van volhoubare ontwikkeling geskuif het
}

\author{
J.A. du Pisani \\ Vakgroep Geskiedenis \\ Skool vir Sosiale en Owerheidstudies \\ Potchefstroomkampus \\ Noordwes-Universiteit \\ POTCHEFSTROOM \\ E-pos: kobus.dupisani@nwu.ac.za
}

\begin{abstract}
New wine in old wineskins? How the moral basis of sustainable development shifted

This article traces the shift in the moral arguments in the sustainable development discourse, which occurred between 1972 and 2002. In the early 1970s ecological considerations were dominant and the zero-growth option had strong support. By the end of the 1980s the influential report of the Brundtland Commission recommended that the balance between the ecological, economic and social aspects of sustainable development ought to be maintained. From the 1990s there was a shift to poverty alleviation as the main focus of the sustainable development discourse. Representatives of the developing countries started making valuable contributions to the evolution of the concept of sustainable development and succeeded in merging the sustainable development discourse into the wider North-South debates. A decrease in wealth rather than a decrease in poverty would be the correct approach to the achievement of sustainable development. However, such a radical change of course would only be possible once considerable progress has been made towards redressing the imbalances in the current global dispensation.
\end{abstract}




\section{Opsomming}

\section{Nuwe wyn in ou sakke? Hoe die morele grondslag van volhoubare ontwikkeling geskuif het}

In hierdie artikel word aangetoon dat 'n duidelike verskuiwing tussen 1972 en 2002 in die morele argumente rondom die diskoers van volhoubare ontwikkeling plaasgevind het. In die vroeë sewentigerjare is ekologiese oorwegings benadruk en het die opsie van geen verdere ekonomiese groei sterk steun geniet. Aan die einde van die tagtigerjare het die invloedryke verslag van die Brundtlandkommissie aanbeveel dat 'n balans tussen ekologiese, ekonomiese en sosiale oorwegings gehandhaaf moet word. Sedert die negentigerjare was die fokus in die volhoubare ontwikkelingsdiskoers op armoedeverligting. Verteenwoordigers van die ontwikkelende lande het mettertyd belangrike bydraes tot die evolusie van die konsep van volhoubare ontwikkeling gelewer en daarin geslaag om die volhoubare ontwikkelingsdiskoers deel te maak van die breër Noord-Suiddebat. In werklikheid behoort die fokus op die vermindering van rykdom eerder as die vermindering van armoede te wees in die nastrewing van volhoubare ontwikkeling. So 'n radikale verandering in benadering sal egter nie moontlik wees voordat daar nie baie ver gevorder is in die uitskakeling van die ongelykhede in die huidige globale bedeling nie.

\section{Inleiding}

Morele oorwegings het sterk gefigureer in die opkoms van die konsep van volhoubare ontwikkeling sedert die sewentigerjare. Hierdie morele kwessies het breedweg rondom twee terreine gesentreer:

- Die mens se morele verpligting teenoor die natuurlike omgewing en

- Welvarende samelewings se verpligting teenoor arm samelewings

Daar was dus sowel 'n ekologiese as 'n sosio-ekonomiese komponent in die morele diskoerse rondom volhoubare ontwikkeling. In hierdie artikel is die redenasie dat die ekologiese morele argument in die 30 jaar tussen 1972 en 2002 relatief tot die sosio-ekonomiese morele argument ter regverdiging van volhoubare ontwikkeling verswak het. In die konteks van Noord-Suiddebatte het die stem van Afrika 'n bydrae hiertoe gelewer. Daar word ook aangevoer dat dit 'n oorvereenvoudiging sou wees om te beweer dat die morele regverdiging van die noodsaak van volhoubare ontwikkeling van 'n 
oorwegend ekosentriese grondslag na 'n oorwegend antroposentriese grondslag verskuif het. Daar was 'n komplekse interaksie van baie oorwegings in die morele diskoers rondom volhoubare ontwikkeling. Seminale tekste en uitsprake tydens die verskillende fases van die evolusie van die konsep volhoubare ontwikkeling word ontleed om klemverskuiwings aan te dui.

\section{Dit kom van ver af: historiese wortels van die konsep volhoubare ontwikkeling}

Om die morele inhoude van die konsep van volhoubare ontwikkeling beter te begryp, is dit nodig om die wortels van die konsep histories na te gaan. Hierdie wortels is elders vollediger ontleed (Du Pisani, 2006).

\subsection{Die idee van vooruitgang}

Denke rondom die ontwikkelingskomponent van volhoubare ontwikkeling spruit histories uit vroeëre opvattings oor vooruitgang, groei en ontwikkeling. Idees oor menslike vooruitgang, dit wil sê beweging vorentoe in 'n gewenste rigting, ten opsigte van wetenskaplike en tegnologiese kennis, materiële welvaart en morele ontwikkeling, is al in die Grieks-Romeinse wêreld geartikuleer. In die Joodse en Christelike godsdienste het hierdie denkrigtings meer aandag geniet (veral Augustinus se sienings was belangrik in hierdie verband). Uiteindelik het vooruitgang feitlik sinoniem geword met die Westerse moderniteit. Denkers soos Fontenelle, Turgot, Condorcet, Saint-Simon, Comte, Hegel, Marx, Kant en Spencer het almal belangrike bydraes gelewer tot die evolusie van die groot idee van vooruitgang, 'n positivistiese siening dat 'n "wet van vooruitgang" bestaan, wat die onkeerbare en onomkeerbare stap vir stap vooruitgang van die mensdom tot 'n goue era op aarde onvermydelik maak. Die idee van vooruitgang is gesekulariseer: dit het wegbeweeg van opvattings oor progressie in 'n goddelik verordineerde rigting na 'n beloofde land anderkant die graf, na beskouings oor 'n beter lewe hier op aarde, wat deur wetenskaplike en tegnologiese ontwikkeling bewerkstellig kan word. In hierdie sin het vooruitgang die gesekulariseerde erfgenaam geword van die Christelike verlossingsideaal (vir besonderhede oor die evolusie van vooruitgangsdenke kyk onder meer Bury, 1932; Edelstein, 1967; Dodds, 1973; Nisbet, 1980; Burgen, McLaughlin \& Mittelstrass, 1997).

Wat mens-omgewingsverhoudings betref, was die argument dat die wetenskap aan die mens meesterskap oor die natuur verleen om die aarde se bronne te tem en ten bate van vooruitgang te benut. Ty- 
dens die Industriële Revolusie is die idee van menslike vooruitgang aan ekonomiese groei en materiële welvaart gekoppel en het die opvatting posgevat dat dit aanvaarbaar en nodig vir die mens is om natuurlike hulpbronne tot die maksimum te benut in die najaag van hoër ekonomiese produksie (Worster, 1993:178-180). Dit het die negatiewe uitwerking gehad dat ontginning van natuurlike hulpbronne op 'n voorheen ongekende skaal geweldige skade aan die fisiese omgewing aangerig het, terwyl die gaping tussen ryk en arm samelewings terselfdertyd groter geword het.

\subsection{Opkoms van die konsep van volhoubaarheid}

Die opvatting van vooruitgang het sy eie teenpool, naamlik die konsep van volhoubaarheid, in aanskyn geroep namate by mense 'n bewussyn van die kwesbaarheid van natuurlike hulpbronne ontwikkel het. Die impak van die vraag na grondstowwe op die omgewing was dwarsdeur die geskiedenis van die mensdom 'n vraagstuk. Die antieke beskawings het reeds daarmee geworstel en in die geskrifte van Plato, Strabo, Columella, Plinius die Ouere en Varro bestaan getuienis van hierdie worsteling. Veral vanaf die agtiende eeu is kommer uitgespreek oor die moontlike tekorte aan primêre grondstowwe vir energieverskaffing, naamlik hout, steenkool en aardolie. Namate wetenskaplike navorsing toegeneem het, is ook aandag aan die kwessie van die volhoubare benutting van hulpbronne gegee. 'n Wetenskaplike benadering tot "volhoubare opbrengs" is reeds in die agtiende-eeuse Duitse bosboukringe ontwikkel. Gedurende die negentiende eeu het onder meer W. Stanley Jevons, Rudolf Clausius, John Stuart Mill, George Perkins Marsh en Alfred Russell Wallace geskryf oor sake wat eers meer as 'n eeu later die kwessie van volhoubare ontwikkeling genoem is. In die vroeë twintigste eeu is hulle werk voortgesit deur wetenskaplikes soos Gifford Pinchot, G.A. Brender à Brandis, F.M. Jaeger, Thorstein Veblen, A.C. Pigou, Egbert de Vries, William Vogt, Henry Fairfield Osborn en K.W. Kapp. (Die geskiedenis van opvattings oor volhoubaarheid word omvattend bespreek in Van Zon, 2002).

\subsection{Verwagtings van onbeperkte ekonomiese groei}

Tussen 1800 en 1970 het die langste en mees ongeëwenaarde periode van ekonomiese groei in die wêreldgeskiedenis plaasgevind, met die hoogste groeikoers in die tydperk ná die Tweede Wêreldoorlog. Dit het optimisme oor die moontlikheid van onbeperkte ekonomiese groei en voortdurend stygende welvaart laat ontstaan. Terselfdertyd het die groeiende gaping tussen ryk en arm in die koloniale tydperk ' $n$ brandende ekonomiese en morele kwessie 
geword. Op die ekonomiese terrein sou die hoë internasionale groeikoerse slegs gehandhaaf kon word indien wêreldmarkte aanhou uitbrei. Dit kon slegs verwesenlik word indien rykdom meer eweredig wêreldwyd versprei word om uiteindelik ook in die ontwikkelende gebiede 'n hoër vraag na produkte te stimuleer. Op die morele vlak was die vraag brandend hoe die steeds ryker wordende samelewings van die ontwikkelde wêreld met hulle gewete kon saamleef, terwyl al hoe groter getalle arm mense in die ontwikkelende "Derde Wêreld" in die uiterste ellende gedompel is.

\subsection{Ontwikkelingsteorieë}

Om oplossings vir die problematiek van die tweede helfte van die twintigste eeu te probeer vind, het verskillende teorieë oor ontwikkeling in 'n wêreld met 'n skerp verdeling tussen 'n ryk "Noorde" en 'n arm "Suide" na vore gekom.

Die argument van die moderniseringsteorie was dat die ontwikkelende lande volgens die voorbeeld van die ontwikkelde lande sou ontwikkel deur ook die pad van vrye ondernemerskap en 'n markekonomie te volg. Indien markte oopgestel word, ekonomieë maksimaal geprivatiseer word en internasionale kapitaal toegelaat word om onbelemmerd te groei, sou die minder ontwikkelde gebiede van die wêreld uiteindelik ook kan deel in die groeiende welvaart en sou armoede dus verminder word.

Daarteenoor het die dependensieteorie aangevoer dat die voortgesette dominasie van die ontwikkelde "kern" van die wêreld juis gebou word op beheer oor en uitbuiting van die minder ontwikkelde "periferie". Westerse ontwikkeling was afhanklik van die doelbewuste onderontwikkeling van die nie-Westerse wêreld en die handhawing van ongelykhede tussen die Noorde en Suide. Daarom sou die ontwikkelende lande slegs kon ontsnap aan die spiraal van armoede deur hulle bande met die kapitalistiese stelsel te verbreek en 'n outonome sosialistiese koers in te slaan (vgl. Peet, 1999; So, 1990).

Hierdie ontwikkelingsteorieë het help vorm aan die denkklimaat waarbinne volhoubare ontwikkeling as 'n nuwe ontwikkelingsparadigma sou ontstaan. 


\section{Red die planeet: die ekologiese diskoers}

\subsection{Vooruitgang as 'n mite ontmasker}

In die laat sestiger- en vroeë sewentierjare het die smeltkroes van idees oor vooruitgang, volhoubaarheid, groei en ontwikkeling, wat oor eeue heen deur verskillende permutasies beweeg het, in die rigting van 'n nuwe paradigma begin wys. Hierdie nuwe paradigma sou as volhoubare ontwikkeling bekend word. In daardie stadium is die groot idee van vooruitgang ontmasker as die mite van vooruitgang. Dit was duidelik dat die hoop op die liniêre en voortgesette verbetering van die menslike toestand beskaam het, omdat dit nie met menslike beperkings rekening gehou het nie. Vooruitgang op wetenskaplike en tegnologiese gebied is skynbaar onstuitbaar voortgesit, maar wat materiële en morele welsyn betref is die progressie van menslike samelewings telkens deur regressie afgewissel. Die vernietiging deur twee wêreldoorloë, die koloniale uitbuiting van nieWesterse samelewings en die plundering van die aarde se biosfeer het pynlik gedemonstreer dat die volmaakte toestand die mensdom nie in hierdie gebroke bedeling beskore is nie.

\subsection{Bewuswording van die ekologiese krisis}

Dit was juis 'n akute bewussyn van die ontsaglike skade wat wetenskaplike, tegnologiese en ekonomiese vooruitgang aan die natuurlike omgewing aangerig het, wat 'n nuwe benadering tot ontwikkelingsvraagstukke genoodsaak het. Rachel Carson se boek The silent spring (1962), word beskou as dié boek wat veral in die VSA as sneller gedien het vir die opkoms van die "groen beweging". In talle ander publikasies, onder meer Paul Ehrlich se The population bomb (1968), Edward Goldsmith se A blueprint for survival (1972) en Fritz Schumacher se Small is beautiful (1973), is alarm gemaak oor die dreigende ekologiese krisis, wat selfs daarop kon afstuur dat die mensdom die aarde se vermoë kon vernietig om lewe te onderhou en sodoende ook hulle eie voortbestaan in gevaar kon stel.

Snelle bevolkingsgroei, omgewingsbesoedeling en die uitputting van nie-hernubare natuurlike hulpbronne is as die ernstigste omgewingsprobleme geïdentifiseer. In die media en populêre kultuur het die omgewing sterker as ooit gefigureer. In verskeie gedaantes het hierdie groen beweging die openbare aandag getrek, onder meer in anti-kernwapenaktiviste, omgewings-nieregeringsorganisasies en groen politieke partye. Ekologisme is as ' $n$ afsonderlike ideologie erken. Die groenes het, binne 'n netwerk van linkse bewegings, 'n 
merkbare politieke impak in Westerse lande gemaak. Vrese oor 'n dreigende ekologiese katastrofe het die weg gebaan vir volhoubare ontwikkeling as alternatief vir onbeperkte ekonomiese groei.

\subsection{Ontstaan van die term volhoubare ontwikkeling}

In die vroeë sewentigerjare het die term volhoubare ontwikkeling in tekste begin opduik (Goldsmith, 1972:23; Meadows et al., 1972:24, 158; vgl. ook Coomer, 1979; Allen, 1980). Daar word beweer dat Barabara Ward (Lady Jackson), stigter van die International Institute for Environment and Development, dié term geskep het. Die konseptuele grondslae van die begrip volhoubare ontwikkeling is in daardie periode in verskeie publikasies vasgelê. In wese het dit daarop neergekom dat volhoubare ontwikkeling daarop afgestem was om 'n toestand in die wêreld te skep waar daar in die basiese materiële behoeftes van alle mense voorsien word. Hierdie voorsiening moet plaasvind op 'n ontwikkelingsvlak wat onbepaald tot in die verre toekoms volgehou kon word, sonder om die aarde se natuurlike hulpbronne tot onherstelbare vlakke uit te put. Voorheen is ontwikkeling en die benutting van hulpbronne as botsende idees, teenoor bewaring en die beskerming van hulpbronne, beskou. Volhoubare ontwikkeling het nou 'n kompromis probeer bewerkstellig, deur ontwikkeling en bewaring as interafhanklike kwessies voor te hou.

\subsection{Erkenning van die beperkings op groei}

Die oliekrisis van 1973 het die potensiële gevolge van hulpbrontekorte dramaties gedemonstreer. Kort daarna het 'n uitgerekte wêreldwye ekonomiese resessie aangebreek. Ontleding van die oorsake van die resessie het gelei tot 'n besef van die beperkings op groei. Daar was steeds idealistiese ekonome wat volgehoue hoë groei voorgestaan het. Hulle het geargumenteer dat die mensdom in staat was om deur nuwe wetenskaplike ontdekkings en die ontwikkeling van verbeterde tegnologieë die ernstige omgewingsprobleme, wat in die weg van verdere ontwikkeling kon staan, te oorkom. Die meer realistiese ekonomiese siening, wat sterker op die voorgrond getree het, het egter daarop gedui dat die vroeëre verwagtings van snelle nywerheidsontwikkeling en hoë groeikoerse nie meer haalbaar was nie. Daar was 'n besef dat dit onmoontlik was dat alle samelewings tot dieselfde ekonomiese vlak kon ontwikkel as dié wat in die ontwikkelde lande bereik is. Daar is eenvoudig nie genoeg bronne op die aarde om sulke hoë verbruik te onderhou nie. Ontwikkelingsmikpunte vir die ontwikkelende samelewings moes beperk word tot ' $n$ peil wat toereikend was om in die basiese 
behoeftes van alle mense te voorsien. Terselfdertyd moes dit sensitief wees vir die kwesbaarheid van die omgewing. Kwalitatiewe ontwikkeling eerder as kwantitatiewe groei moes nagestreef word (vgl. onder meer Rostow, 1978:580-581; Paxton, 1993:2; Viedermann, 1993:181).

Hierdie besef het aangesluit by die seminale teks uit daardie era, naamlik The limits to growth. Hierdie publikasie was die resultaat van 'n navorsingsprojek wat in opdrag van die Club of Rome, 'n groep vooraanstaande ekonome en wetenskaplikes, uitgevoer is. Rekenaarsimulasies is gebruik om die impak van die benutting van die aarde se fisiese hulpbronne te ondersoek. Die skrywers van die navorsingsverslag het gewaarsku dat die aarde oor beperkte natuurlike hulpbronne beskik. Hulle byna apokaliptiese slotsom was dat, indien die groeitendense in die wêreld se bevolkingsgroei, industrialisasie, besoedeling, voedselproduksie en die uitputting van hulpbronne teen dielfde tempo bly voortduur, die grense van groei op die planeet binne minder as 'n eeu bereik sou word. Dit kan tot 'n skielike en onbeheerbare afname in die bevolking en nywerheidskapasiteit lei (Meadows et al., 1972:23). Omdat Limits to growth 'n hewige debat aan die gang gesit het oor die moontlikheid en haalbaarheid van onbeperkte ekonomiese groei en oor die noodsaaklikheid om 'n alternatief daarvoor te vind, word dit beskou as 'n sleutelbydrae tot die ontstaan van die konsep van volhoubare ontwikkeling (Kenny, 1994:229; Rostow, 1978:571).

In hierdie stadium, voordat 'n duidelike beeld van die volle omvang van die postkoloniale sosio-ekonomiese dilemmas van die Derde Wêreld gevorm is, was die ekologiese diskoers dominant in debatte rondom die begrip volhoubare ontwikkeling. Van die kernvrae in die ekologiese diskoers wat aan die orde gekom het, was: Is die mens die meester van die natuur of die kind daarvan? Tot op watter punt mag die mensdom die aarde se natuurlike hulpbronne benut? Wanneer gaan gebruik oor in oorbenutting en misbruik?

\subsection{Debat oor die Christendom en die ekologiese krisis}

Vanuit die Christelike perspektief is belangrike insette in die diskoers oor volhoubare ontwikkeling gelewer in reaksie op kritiek oor die Christelike godsdiens se beweerde rol in die plundering van die natuur. Reeds vroeg in die twintigste eeu het Max Weber 'n verband gelê tussen die Calvinistiese uitverkiesingsleer en die Westerse gees van kapitalisme, met die suggestie dat die Christendom aandadig was aan omgewingsagteruitgang (Weber, 1990). 
Lynn White het in 'n omstrede artikel in die laat sestigerjare JudeoChristelike antroposentrisme vir die plundering van die aarde se natuurlike omgewing blameer. Volgens hom het die omgewingsvernietigende magte van wetenskap, kapitalisme, tegnologie en demokrasie almal uit 'n godsdienstige oorsprong, naamlik die Middeleeuse Christendom, gespruit. White se argument was dat die Christendom se oorwinning oor heidense animisme die respek vir die heiligheid van die natuur omvergewerp het. Daardeur is die beperkings wat mense verhinder het om die natuur te misbruik, uit die weg geruim. Die opvatting dat die mens, volgens Genesis 1:28 in die Bybel, die natuur moet onderwerp en beheer, het 'n houding van arrogansie onderliggend aan die plundering van die natuur gesanksioneer. White was van mening dat 'n religieuse oplossing gevind moes word. Hy het voorgestel dat die Franciskaanse siening van die spirituele outonomie van alle dele van die natuur, wat in sekere Christelike kringe as ketters uitgemaak is, as vertrekpunt geneem kon word om 'n nuwe rigting in te slaan (White, 1967; vgl. ook Young, 1994:10).

White se beskuldiging het 'n heftige debat ontketen. In een argumentsrigting is uitgewys dat daar wél 'n denktradisie in die Christendom bestaan het waarvolgens die mens ' $n$ absolute mandaat van God gekry het om die natuur te onderwerp. Hiervolgens was die mens die kroon van die skepping en is die natuur vir die mens gemaak. Die naturalisme van die "heidense" samelewings is op 'n militante wyse teengestaan as afgodery. Volgens Christendenkers soos Anselmus, Augustinus en Thomas van Aquinas was die natuur nie heilig nie en was die aanwending van tegnologie in belang van produksie dus legitiem. Hierdie antroposentriese benadering het Westerse denke, in teenstelling met Oosterse opvattings, in 'n bepaalde koers (dié van die positivistiese vooruitgangsdenke) gestuur en die ideologiese, opvoedkundige en administratiewe grondslag gelê vir 'n samelewing wat op ekonomiese groei ingestel is. Met die wetenskaplike revolusie en die opkoms van kapitalisme het die bewussyn van die mens se mag toegeneem en uiteindelik uitgemond in "a breathtaking anthropocentrism, based on his power over nature, unmatched by anything in the past" (Glacken, 1967: 494).

'n Reeks beskuldigings is teen die Christendom ingebring, onder meer die volgende:

- Die beweerde Bybelse opvatting van die mens se meesterskap oor die natuur is aangewend om die natuur vir die mens se selfsugtige doeleindes te plunder. 
- Christelike kerke gee nie voldoende samewerking in die beheer van bevolkingsgroei deur geboortebeperking nie.

- Westerse antroposentrisme het uit die Christelike teologie voortgespruit.

- Joods-Christelike monoteïsme het die geloof in die goddelikheid van die natuur vernietig.

- Die Christendom het die milieu geskep vir die opkoms van die moderne wetenskap en tegnologie, wat op die onbelemmerde onderwerping van die natuur uitgeloop het.

- Die dualisme tussen die geestelike en materiële wêreld het tot 'n devaluering van die fisiese omgewing gelei.

- Eskatologiese verwagtings dat die aarde op vernietiging afstuur, het besorgdheid oor die staat van die planeet afgestomp (Young, 1994:12-17).

Verdedigers van die Christelik-etiese denke het toegegee dat daar teenstrydighede was tussen wat die Bybel oor die mens-natuurverhouding leer en hoe die kerk dit soms vertolk het. Hulle het egter geantwoord dat daar, naas die tradisie wat die mens as meester oor die natuur beskou, ook 'n ander groeiende tradisie in die Christendom was, wat op Genesis 2:15 gebaseer is. Hiervolgens is die natuur God se eiendom en is die mens slegs 'n tydelike rentmeester wat later volle rekenskap van sy rentmeesterskap moet gee. Christene wat hierdie tradisie volg, is nie arrogant teenoor die natuur nie, maar onderskryf 'n etiek van sorg vir die aarde. Baie Christene het erken dat godsdiens ' $n$ belangrike rol in die hantering van die ekologiese krisis moet speel en het inderdaad self 'n leidende rol in omgewingsbewaring gespeel (vgl. onder meer Worster, 1993:187189; Pepper, 1986:44-46; Young, 1990:54 e.v.).

Uit hierdie debat in Christelike kringe het sedert die sewentigerjare 'n omvangryke literatuur oor Christelike rentmeesterskap ten opsigte van die omgewing gegroei (vgl. onder meer Wilkinson, 1980; 1991; Vorster, 1987; Vos \& Muller, 1991; Basney, 1994; Young, 1994; Northcott, 1996; Van Dyke, 1996; Gousmett \& Chimuyka, 1997). "Earthkeeping" word deur Wilkinson et al. (1991:2, 254, 306, 325, 350-359) as die taak van die Christendom geïdentifiseer - 'n taak waarop Christene hulle harte individueel en kollektief moet instel. Versoening moet nie net tussen God en mens en mens en mens plaasvind nie, maar ook tussen mens en skepping. Volgens hierdie outeurs is die Skrifte se visie van die hemelse koninkryk een van die 
mens wat in harmonie met die skepping is. Hulle onderskei 'n aantal beginsels vir Christelike rentmeesterskap en verskaf riglyne vir optrede in die uitvoering van hierdie rentmeesterskap.

\subsection{Die eerste internasionale omgewingskonferensie}

Verskillende voorstelle is in die sewentigerjare gemaak om die dreigende ekologiese krisis die hoof te bied. Limits to growth het 'n ekwilibriumstaat (basies 'n zero-groei-opsie ten opsigte van bevolking en kapitaal) aan die hand gedoen (Meadows et al., 1972:170184). Volgens Small is beautiful kon aan die onmenslike druk van die moderne nywerheidsamelewing ontsnap word deur in kleiner gemeenskappe 'n selfversorgende leefstyl in harmonie met ander mense en met die natuur te volg. Voorstelle is gemaak oor hoe eienaarskap van groot ondernemings in die openbare belang herstruktuur kon word (Schumacher, 1973:68, 264-273).

Die idee dat 'n drastiese strukturele transformasie van die wêreld se ekonomiese stelsel nodig was om die planeet te red, het ook opgeduik by die eerste groot internasionale omgewingskonferensie wat deur die VN gereël is - die United Nations Conference on the Human Environment (UNCHE) wat in 1972 in Stockholm plaasgevind het. In die verklaring wat deur die konferensie uitgereik is, is omgewingsbewaring vooropgestel deur die volgende stelling in die inleiding:

To defend and improve the human environment for present and future generations has become an imperative goal for mankind. (UNCHE, 1972: art. 6.)

Daar is in die verklaring gewys op die vermoë van die mens om deur wetenskap en tegnologie die omgewing op 'n voorheen ongekende skaal te transformeer en op die skade wat reeds aan die omgewing aangerig is. Volgens die verklaring het dit absoluut noodsaaklik geword om die omgewing se natuurlike hulpbronne deur versigtige beplanning en bestuur vir die huidige en toekomstige geslagte te beskerm en te verbeter. Individuele burgers, gemeenskappe en regerings moet gesamentlik die verantwoordelikheid hiervoor aanvaar. Verskeie van die verklaring se artikels en beginsels handel oor die hantering van spesifieke omgewingsprobleme (UNEP, 2007a).

Die opkoms van die groen beweging en die betreklik radikale voorstelle wat gemaak is om die planeet van 'n ekologiese ramp te red, was tiperend van die Zeitgeist van die laat sestiger- en vroeë sewentigerjare. Dit was 'n era waarin meer radikale linksgesinde 
denke en politieke bewegings (byvoorbeeld die New Left in die VSA) tydelik sterk op die voorgrond getree het in Westerse samelewings. Hierdie linkse inslag, wat redelik dominant was in baie van die morele diskoerse van daardie tyd, spesifiek ook oor die mens se verhouding met die natuurlike omgewing, sou spoedig weer deur meer konvensionele standpunte teruggedring word.

\section{Red die armes: die sosio-ekonomiese diskoers}

\subsection{Die ontwikkelende wêreld skepties oor volhoubare ontwikkeling}

Uit die wyse waarop die teks van die UNCHE-verklaring in 1972 geformuleer is, blyk duidelik dat ernstige Noord-Suiddebatte agter die skerms plaasgevind het. Ontwikkelende lande het uiteraard aan ander oorwegings as ontwikkelde lande prioriteit verleen. Vir die ontwikkelende lande was ekonomiese groei 'n prioriteit, aangesien dit noodsaaklik was om welvaart te skep, hulle lewenstandaarde te verhoog en agterstande in vergelyking met die ontwikkelde lande in te haal. Gevolglik was baie van die ontwikkelende lande se leiers skepties en wantrouig oor die konsep van volhoubare ontwikkeling. Veral die gedagte dat groei beperk moes word, is baie skepties ontvang, omdat hulle bang was dat dit deur die Noorde as 'n strategie aangewend kon word om groei in die Suide te blokkeer. Op 'n stadium toe die dekolonisasieproses van die voormalige kolonies byna op die politieke terrein voltrek was, het die sogenaamde Derde Wêreld ook ekonomiese en ekologiese kolonialisme uitgedaag.

By die UNCHE is die ryk lande geblameer vir die vernietiging van die omgewing en die verarming van die bevolkings in die ontwikkelende lande. Daar is aangevoer dat dit bitter onbillik sou wees om nou weer die arm lande die spit vir die wêreld se omgewingsprobleme, waarvoor veral die ontwikkelde lande verantwoordelik was, te laat afbyt. Dit sou vir hulle onmoontlik word om hulle mense se lewensomstandighede te verbeter indien ekonomiese groei aan bande gelê word. Kommer is deur die afgevaardigdes van die ontwikkelende lande uitgespreek dat die konferensie te veel aandag aan die fisiese omgewing en te min aan die sosiale omgewing gegee het. Die dringendste taak was juis om die armoede, wanvoeding en ongeletterdheid van twee-derdes van die wêreldbevolking te verminder. Derde Wêreld-sprekers het die gedagte onderskryf dat optrede ten bate van omgewingsbewaring nie as 'n verskoning gebruik mag word om ontwikkeling te verminder nie. Inteendeel, ontwikkelingshulp moes aansienlik uitgebrei word. Onder verteen- 
woordigers van die ontwikkelende lande was daar algemene instemming dat 'n filosofie van geen groei (soos in Limits to growth voorgestel is) absoluut onaanvaarbaar was. 'n Beroep is op ontwikkelde lande gedoen om hulle benadering drasties te verander, deur onder meer beskermende handelstariewe op te hef (UNEP, 2007b).

Kompromieë moes tussen die teenstellende benaderings van die ontwikkelde en ontwikkelende lande aangegaan word en dit word op verskeie plekke in die teks van die UNCHE-verklaring weerspieël. Die reg van alle mense op die ontwikkeling en verbetering van hulle lewenskwaliteit is bevestig, veral ook mense in die ontwikkelende lande. Die belangrikheid van menslike behoeftes en aspirasies is beklemtoon. Verskeie van die 26 beginsels in die verklaring het spesifieke verwysings na die ontwikkelende lande bevat. Sake soos verhoogde tegniese en finansiële hulp aan ontwikkelende lande om hulle in staat te stel om die omgewing te beskerm, en beter en meer stabiele pryse vir die grondstowwe, wat deur die ontwikkelende lande aan die ontwikkelde lande gelewer is, is gepropageer (vgl. UNEP, 2007a).

Die subteks van die uitkoms van die UNCHE was dus dat daar in beginsel deeglik kennis geneem is van die behoeftes van die ontwikkelende wêreld, hoewel daar nog geen vaste verbintenisse was om noodwendig hierdie behoeftes te bevredig nie.

Uit bogenoemde is dit duidelik dat so vroeg as by die 1972-konferensie in Stockholm daar reeds naas die sterk ekologiesgerigte diskoers, wat byvoorbeeld in Limits to growth oorheers het, 'n ander diskoers op die voorgrond begin tree het. In kringe waar die ontwikkelende lande inspraak gehad het, soos by geleenthede wat deur die VN gereël is, het hierdie ander diskoers wat op die oplossing van die sosio-ekonomiese problematiek van die Derde Wêreld gerig was, ' $n$ impak op internasionale agendaskepping en beleidsbepaling begin uitoefen. Die sentrale morele kwessie in hierdie konteks was die vraag hoe ver die ryk samelewings se verpligting gestrek het om die arm samelewings te help om hulle lewensomstandighede te verbeter.

\subsection{Rol van die Brundtlandkommissie}

In die tagtigerjare het wye mediadekking aan omgewingsrampe en - probleme die spook van moontlike ekologiese rampspoed lewend gehou. Al meer verdoemende wetenskaplike gegewens oor die potensiële negatiewe gevolge van spesifieke vraagstukke, soos die 
kweekhuiseffek en die gat in die osoonlaag, het aan die lig gekom en die omgewingsproblematiek in die openbare aandag gehou. Die omvang van die humanitêre krisis wat met die toenemende armoedespiraal in Afrika geassosieer is weens dié kontinent se dramatiese ekonomiese agteruitgang sedert die sewentigerjare, het algaande begin ontvou. Teen hierdie agtergrond het nuwe permutasies rondom die konsep van volhoubare ontwikkeling uit die interaksies tussen die verskillende ekonomiese, sosiale en ekologiese diskoerse gevloei.

Weereens het die VN deur die Brundtlandproses 'n rigtinggewende koers aangedui. Deur ' $n$ resolusie van die Algemene Vergadering van die VN in 1983 is die Wêreldkommissie oor die Omgewing en Ontwikkeling, of die sogenaamde Brundtlandkommissie, geskep om 'n omgewingsperspektief tot die jaar 2000 en daarna te ontwikkel. Dié kommissie moes uit die staanspoor 'n kompromisbenadering volg om die belange van die ontwikkelde en ontwikkelende lande te probeer versoen en samewerking tussen hulle op die gebied van omgewingsvraagstukke te probeer bewerkstellig. Om gemeenskaplike en wedersyds ondersteunende doelstellings met betrekking tot die aanpak van omgewingsprobleme te formuleer, was 'n belangrike oogmerk van die kommissie. In die VN-resolusie is die hoop uitgespreek dat gedeelde persepsies rondom omgewingskwessies daargestel kon word en ook dat geskikte aksies geloods kon word om hierdie kwessies te hanteer (UNGA, 1983). Die Brundtlandkommissie is sodanig gestruktureer en die werksaamhede daarvan so beplan dat sowel die ontwikkelde as die ontwikkelende lande voldoende geleentheid vir insette gekry het (UNGA, 1987).

Our common future, die verslag van die Brundtlandkommissie wat in 1987 voltooi is, het verklaar dat die groot omgewingsvraagstukke van die wêreld die gevolg is van die onvolhoubare verbruikerspatrone in die Noorde, wat in teenstelling met die enorme armoede in die Suide gestaan het. Die gevolgtrekking van die verslag was dat ekonomiese groei noodsaaklik was, veral in die ontwikkelende lande, maar dat dit volhoubaar moes geskied sonder om die natuurlike omgewing verder in die proses te vernietig. Daar is beklemtoon dat die ekologiese, sosiale en ekonomiese subkomponente van volhoubare ontwikkeling deurgaans in ag geneem moes word (UNGA, 1987:19-25).

'n Duidelike sein is deur Our common future uitgestuur dat die zerogroei-opsie nie as haalbaar beskou word nie en dat ekologiese oorwegings nie voorrrang bo sosiale en ekonomiese oorwegings behoort te geniet nie. 


\subsection{Armoedeverligting begin sterk figureer}

Belangrike studies uit hierdie periode, soos die World Conservation Strategy (IUCN, 1980) en Caring for the Earth (IUCN, 1991), het volhoubare ontwikkeling baie sterk aan armoedeverligting begin koppel. Die onderliggende aanname was dat arm mense hulle plaaslike omgewing vernietig omdat hulle geen ander keuse het in hulle stryd om oorlewing nie. Armoede moes daarom vir sowel sosiale as ekologiese redes verminder word. Hierdie sentiment is soos volg uitgedruk (IUCN, 1980:6):

Hundreds of millions of rural people in developing countries, including 500 million malnourished and 800 million destitute, are compelled to destroy the resources necessary to free them from starvation and poverty.

In die Suid-Afrikaanse uitgawe van Caring for the Earth is dit soos volg gestel (Yeld, 1997:17; vgl. ook Singhal \& Shrivastava, 2004: 330, 334):

Poverty is one side of the coin of environmental destruction ... impoverished and over-crowded communities are battling to survive. In such circumstances, environmental ethics are often considered irrelevant and conservation concerns written off as an unnecessary luxury in the never-ending struggle for survival.

Idees oor armoedeverligting het aangesluit by 'n konsep wat uit die diskoers oor volhoubare ontwikkeling gespruit het, naamlik dié van billikheid binne dieselfde generasie ("intra-generational equity"). Daarvolgens moes hulpbronne sodanig benut word dat billikheid teenoor alle mense van die huidige geslag geskied, sowel op die plaaslike as die internasionale vlak (vgl. Center for International Environmental Law, 2007).

\subsection{Die Rio Aardeberaad}

In die negentigerjare het die klem in volhoubare ontwikkelingsdiskoerse al meer na armoedeverligting as prioriteit verskuif. Hierdie tendens het reeds by die Rio Aardeberaad in 1992 geblyk. Die twee hoofdokumente wat by dié beraad goedgekeur is, naamlik die Rioverklaring oor Omgewing en Ontwikkeling (UN, 1992b - vgl. veral beginsel 5) en Agenda 21 (UN, 1992a - vgl. veral hoofstuk 3), het beklemtoon dat 'n strategie teen armoede een van die basiese voorvereistes vir volhoubare ontwikkeling was.

Die taaiste onderhandelings by die Rio-beraad het gehandel oor finansiële hulpbronne en meganismes, soos uiteengesit in hoofstuk 
33 van Agenda 21 (UN, 1992a). Die G77-lande (die ontwikkelende lande) het aangedring op versekerings dat hulle addisionele fondse sou ontvang om hulle verpligtings onder Agenda 21 na te kom en dat die ontwikkelde lande hulle daartoe verbind om teen die jaar 2000 hulle amptelike ontwikkelingshulp tot 0,7 persent van hulle BNP (bruto nasionale produk) te verhoog. Op die laaste dag van die beraad het die ontwikkelde lande uiteindelik ingestem om hulle hulpprogrammme uit te brei (IISD, 1992).

Die goedgekeurde tekste van die Rio-verklaring en Agenda 21 het gepoog om die belange van die ontwikkelde én ontwikkelende lande te balanseer. Ekonomiese groei, sosiale ontwikkeling en armoedeverligting is as prioriteite geïdentifiseer en die geelwortel van 'n oper internasionale ekonomiese stelsel is uitgehang. Dit is geïnterpreteer as die aanvaarding van sleutelbeginsels wat die ontwikkelende lande se ekonomiese ontwikkeling kon bevorder eerder as om dit verder aan bande te lê (vgl. Anon., 1995).

\subsection{Afrika, armoede en volhoubare ontwikkeling}

Armoede het veral in Afrika 'n al groter probleem geword en kritiese afmetings aangeneem. Twee-derdes van die wêreld se armste lande was in Afrika suid van die Sahara. BBP per capita-groeikoerse in Afrika was baie laag en dit het gelyk asof die kontinent net al verder in 'n see van armoede wegsink. BBP-syfers het aangedui dat die gemiddelde Afrikaan in 1992 tussen 20 en 25 persent slegter daaraan toe was as in 1979 (Seidman \& Anang, 1992:1; World Bank, 2004:26-27).

Vir Afrika was armoede as morele kwessie 'n hefboom ter verkryging van ontwikkelingshulp in die nuwe internasionale opset na die einde van die Koue Oorlog. In daardie stadium het Afrika sy strategiese belang vir die supermoondhede verloor en was daar vrese dat die kontinent al verder gemarginaliseer kon word. Namate die skakels tussen armoedeverligting en volhoubare ontwikkeling versterk is, het Afrikaleiers hulle vroeëre skeptisisme jeens die motiewe agter volhoubare ontwikkeling laat vaar en die konsep begin toeëien as 'n onderhandelingshulpmiddel in die breër Noord-Suiddebatte.

Leiers van die ontwikkelende lande het soos volg geargumenteer: die kolonies is tydens die koloniale tydperk deur hulle Europese koloniale heersers geplunder en uitgebuit; die ontwikkelde lande is minstens gedeeltelik vir die armoede in die ontwikkelende lande verantwoordelik en het daarom ' $n$ verpligting tot kompensasie teenoor die ontwikkelende lande; hierdie verpligting is in die na-koloniale 
era nie nagekom nie en ontwikkelende lande het selfs op 'n neokoloniale patroon voortgegaan om die voormalige kolonies te benadeel. Deur hierdie argumentering kon die leiers van die ontwikkelende lande die morele hoë grond in Noord-Suiddebatte inneem.

By die een na die ander groot VN-konferensie gedurende die negentigerjare is ' $n$ sterk morele verbintenis tot die verligting van die lot van die wêreld se armes gemaak. Resolusies by belangrike internasionale forums het in die teken van kompromieë tussen die botsende ontwikkelingsprioriteite van die ontwikkelde en ontwikkelende lande gestaan. Ten einde globale vooruitgang in die rigting van volhoubare ontwikkeling te fasiliteer, is 'n dringende behoefte aan gedeelde waardes geïdentifiseer. Die twee Afrikane wat in hierdie tydperk in die warm stoel van die VN se sekretaris-generaal gesit het, Boutros Boutros-Ghali (1991-1996) en Kofi Annan (19972006), het besonder klem op armoedeverligting as 'n globale prioriteit gelê (UN, 1996; UN, 1997). Dit was dus geen verrassing dat die vermindering van armoede die eerste plek ingeneem het onder die MDG's (Millennium Development Goals), wat in September 2000 by die VN se Millenniumberaad deur 189 lande aanvaar is nie (UNDP, 2007).

\subsection{Die Wêreldberaad oor Volhoubare Ontwikkeling, Johannesburg 2002}

Dit was onvermydelik dat by die Wêreldberaad oor Volhoubare Ontwikkeling, wat van 26 Augustus tot 4 September 2002 in Johannesburg gehou is, die soeklig sterk sou val op die belange van die ontwikkelende lande en spesifiek ook armoedeverligting. Vooraf het Afrikaministers 'n gemeenskaplike standpunt vir die beraad geformuleer. Hierin is hulle verbintenis tot volhoubare ontwikkeling herbevestig. Kommer is uitgespreek oor die min vordering wat met die implementering van Agenda 21 gemaak is, veral omdat die ontwikkelde lande nie hulle verbintenisse by Rio nagekom het nie. Die uitskakeling van armoede was 'n onontbeerlike voorvereiste vir volhoubare ontwikkeling en moes die hoogste prioriteit geniet. Die Afrikaleiers het gewys op die ongelykhede in die verhouding tussen die ontwikkelde en ontwikkelende lande. Hulle wou hê dat die legitieme ontwikkelingsprioriteite van die ontwikkelende lande erken moes word en dat "gedifferensieerde verantwoordelikhede" ten opsigte van volhoubare ontwikkeling vir die ryk én arm lande moes geld. Volgens hulle was dit die gesamentlike verantwoordelikheid van die Noorde en die Suide om die globale verhoudings, wat 
onderliggend aan die armoede in Afrika was, om te keer (UNEP, 2001).

Die uitskakeling van armoede, die beskerming van natuurlike hulpbronne wat as basis vir ekonomiese en sosiale ontwikkeling moes dien, en die verandering van onvolhoubare patrone van produksie en verbruik was die drie oorkoepelende temas van die Wêreldberaad. In sy openingsrede het President Thabo Mbeki gesê (Anon., 2002a):

A global human society based on poverty for many and prosperity for a few, characterized by islands of wealth surrounded by a sea of poverty, is unsustainable.

Hy het 'n beroep op die ryk lande gedoen om hulle verantwoordelikhede vir die bestryding van armoede en onderontwikkeling te aanvaar (Mbeki, aangehaal in Anon., 2002a).

By die Wêreldberaad se beraadslagings het die uiteenlopende prioriteite van die ontwikkelde en ontwikkelende lande duidelik geblyk. Verteenwoordigers van die arm lande het aangedring op hulle reg tot ontwikkeling en het die onvolhoubare verbruik en produksie van die ryk lande gekritiseer. Op hulle beurt het die verteenwoordigers van die ontwikkelde lande klem gelê op ontwikkelende lande se onvermoë om standaarde vir goeie regering na te kom (Anon., 2002b).

Uiteindelik moes die tekste van die twee amptelike dokumente van die Wêreldberaad, die Johannesburgse Plan van Implementering en die Johannesburgse Verklaring oor Volhoubare Ontwikkeling, redelik afgewater word om konsensus te bereik. Albei dokumente het armoedeverligting uitgelig as die grootste uitdaging vir die wêreld. 'n Beroep is gedoen vir 'n grootse poging op alle vlakke om die ontwikkelende lande te help om hulle armoedeverwante teikens te bereik (aangehaal in Strachan et al., 2005:177).

By die Johannesburgberaad is die neiging voortgesit om in internasionale omgewingsforums minstens ewe veel klem op menslike welsyn as op ekologiese oorwegings te plaas. Dit het gemengde reaksie uitgelok. Volgens kritici het die beraad die arm en kwesbare mense van die wêreld in die steek gelaat deur geen vaste ooreenkomste te bereik oor die drastiese stappe wat nodig was om die planeet se omgewingsprobleme effektief te hanteer nie. Ondersteuners van die proses was egter van mening dat die Wêreldberaad en die reeks voorafgaande $\mathrm{VN}$-konferensies voldoen het aan die vereistes vir konferensiediplomasie deur belangrike kwessies op 
die agenda te plaas, die breër publiek bewus te maak van knelpunte, nuwe inligting te genereer, te werk in die rigting van konsensus en administratiewe hervorming, en massadeelname te bevorder (Baker, 2006:66, 73).

\section{Morele klemverskuiwing: van geen groei na armoedeverligting}

In hierdie artikel is aangetoon dat 'n duidelike verskuiwing tussen 1972 en 2002 in die volhoubare ontwikkelingsdiskoers plaasgevind het. Terwyl die hoofklem in die vroeë sewentigerjare op ekologiese oorwegings geplaas is en die geen-groei-opsie sterk steun in wetenskaplike kringe geniet het, het die rigtinggewende Brundtlandverslag aan die einde van die tagtigerjare benadruk dat daar 'n balans tussen ekologiese, ekonomiese en sosiale oorwegings geskep moes word. Sedert die negentigerjare is die volhoubare ontwikkelingsdiskoers, veral in soverre dit binne die VN se Agenda 21-opset gevoer is, in 'n groot mate oorheers deur die armoedevraagstuk en hoe dit hanteer moet word ten einde volhoubare ontwikkeling op 'n globale skaal te kan aanpak.

Aanvanklik was die verteenwoordigers van die ontwikkelende state skepties oor die konsep van volhoubare ontwikkeling, veral omdat dit die potensiaal gehad het om in konflik te kom met die behoefte aan ekonomiese groei en sosiale ontwikkeling in die arm lande. Sedert die Brundtlandproses is volhoubare ontwikkeling egter geesdriftig omarm. Ondersteun uit radikale kringe in die Weste is daarin geslaag om die volhoubare ontwikkelingdiskoers deel te maak van die breër Noord-Suiddebat oor globale ekonomiese ongelykhede. Ongetwyfeld het die morele gewig van die argumente van diegene wat die saak van die armes van die wêreld gestel het, ondersteun deur 'n groeiende kennisbasis van die realiteite van die globale Suide, 'n belangrike bydrae gelewer tot die evolusie van die konsep van volhoubare ontwikkeling.

Op die oog af lyk die fokus op die nood van arm gemeenskappe altruïsties en moreel aanvaarbaar. Die vraag is egter of die toenemende klem op armoedeverligting vanuit 'n morele perspektief positief of negatief beoordeel word. Daar kan geargumenteer word dat die konsep van volhoubare ontwikkeling 'n groter bewussyn van die interafhanklikheid van sosiale, ekonomiese en omgewingsaspekte geskep het en ook 'n platform daargestel het vanwaar die bestaande globale magsverhoudings in internasionale forums uitgedaag kan word. Dit het die ruimte geskep vir verteenwoordigers van 
die ontwikkelende lande om hulle standpunte meer hoorbaar vir 'n internasionale gehoor te stel. Omdat die gevolge van armoede so 'n emosionele kwessie is, bied dit die geleentheid om 'n morele impak op die ryk samelewings van die Noorde te maak. Dit sou egter naïef wees om te dink dat hierdie morele impak 'n spoedige effek op bestaande globale ongelykhede sal hê.

Daar moet in gedagte gehou word dat die prioriteit wat in internasionale forums aan armoede verleen is, afgespeel het teen die agtergrond van die pogings deur die ontwikkelde lande om die ongelyke globale stelsel in stand te hou. Om prominensie aan armoedeverligting te verleen, het die ontwikkelde lande se leiers gepas. Die gekibbel oor watter persentasie van die ryk lande se BNP vir ontwikkelingshulp afgestaan moes word, het bloot gegaan oor hoeveel aalmoese die ryk lande op hulle eie voorwaardes aan die arm lande behoort te gee. Dit het nie die bestaande Bretton Woods-regime, waar die Wêreldbank, Internasionale Monetêre Fonds en Wêreldhandelsorganisasie 'n sentrale rol in die globale ekonomiese orde speel om die status quo van ongelykheid in stand te hou, direk uitgedaag en dus die gevaar van aandrang op 'n radikale herstrukturering van die ekonomiese magsbalans in die wêreld ingehou nie.

Die ironie is dat ' $n$ benadering van armoedeverligting fokus op die simptome eerder as die ware oorsake van die ekologiese dilemma. In die Brundtlandverslag is die onvolhoubare verbruikerskultuur in die ryk Noorde as die grootste sondebok vir die wêreld se omgewingsprobleme geïdentifiseer. Daar is in ander studies bevind dat die ekologiese voetspoor van mense in welvarende stedelike gemeenskappe in die Westerse metropole baie groter is as dié van mense in arm landelike gemeenskappe in die ontwikkelende wêreld (vgl. Wackernagel \& Rees, 1996). Ryk en magtige mense dra veel meer by tot die vernietiging van die omgewing as die armes en ellendiges. Dikwels word die armes, wat kwalik oor die vermoë beskik om hulle hierteen te verweer, egter geblameer vir omgewingsprobleme.

Die logiese benadering tot die hantering van die ekologiese krisis in die wêreld is om te fokus op die vermindering van rykdom eerder as die vermindering van armoede. Na afloop van die Rio Aardeberaad het die Ecologist-tydskrif aangevoer dat die regime van omgewingsbewaring, wat deur die beraad geskep is, op 'n foutiewe uitgangspunt berus het, omdat nie armoede nie, maar die Westerse styl van rykdom die grondoorsaak van omgewingsdegradasie was (aangehaal in Baker, 2006:60). 
'n Alternatiewe, meer radikale standpunt in die ontwikkelde lande het die ontwikkelende wêreld se posisie binne die volhoubare ontwikkelingdiskoers ondersteun. Hierdie radikale beskouing is veral by byeenkomste van die WSF (World Social Forum) verwoord. Die obsessie met markte en verbruik onder neo-liberale "globalisering" is vir ekologiese nie-volhoubaarheid geblameer. Na bewering is die beheer en mag oor natuurlike hulpbronne deur state en multinasionale maatskappye gesentraliseer. Gewone mense se natuurlike demokratiese reg op toegang tot gemeenskaplike hulpbronne (die sogenaamde commons) moes herstel word. Beroepe is op die welvarende samelewings gedoen om hulle vlakke van produksie en verbruik te verlaag, om sodoende die armer samelewings die kans te gee om 'n beter lewenskwaliteit te geniet. Verder is pleidooie gelewer vir 'n fundamentele herstrukturering van die internasionale politieke en ekonomiese orde deur die bedeling van die Wêreldbank, IMF en WHO met multilaterale omgewingsooreenkomste te vervang (Horton, 2002; Fisher \& Ponniah, 2003:126-128).

Idealiste wat glo dat volhoubare ontwikkeling die weg na 'n beter toekoms baan, sal die hoopvolle slotgedeelte van die Johannesburgse Verklaring oor Volhoubare Ontwikkeling kan onderskryf:

We commit ourselves to act together, united by a common determination to save our planet, promote human development and achieve universal prosperity and peace ... From the African continent, the cradle of humankind, we solemnly pledge to the peoples of the world and the generations that will surely inherit this Earth that we are determined to ensure that our collective hope for sustainable development is realized (UN, 2002).

Uiteenlopende beskouings oor volhoubare ontwikkeling het nog altyd bestaan sedert in die vroeë sewentigerjare begin is om dié term te gebruik. Volhoubare ontwikkeling kon nog nooit daarin slaag om ekstreme standpunte oor ontwikkeling en volhoubaarheid te versoen nie en sal dit ook waarskynlik nooit regkry nie Tog was die diskoers rondom volhoubare ontwikkeling suksesvol in dié opsig dat dit mense bewus gemaak het van alternatiewe perspektiewe en moontlikhede en dat dit sodoende persepsies verander het.

Daar sal nie maklik gehoor gegee word aan die aandrang op die vermindering van rykdom of die radikale herstrukturering van die wêreld se ekonomiese stelsel nie. Vanuit 'n ekonomiese oogpunt beskou is dit onhaalbaar en onwenslik om welvarende mense te probeer oorreed om hulle welvaart te verminder. Dit wat as die norm aanvaar word, in hierdie geval welvaart, word gewoonlik nie onder 
die soeklig geplaas nie, maar eerder dit wat as 'n afwyking van die norm beskou word, naamlik armoede.

By die Johannesburgse Wêreldberaad was die verandering van onvolhoubare patrone van produksie en verbruik weliswaar een van die hooftemas op die sakelys. 'n Paar jaar later is daar nog nie eers begin om die strukturele ongelykhede tussen die ontwikkelde en ontwikkelende state uit die weg te ruim nie. Dit bemoeilik pogings om voldoende druk op die magtigstes te plaas om werklik 'n substansiële bydrae tot omgewingsbewaring en armoedeverligting te maak.

Al is ware volhoubare ontwikkeling vandag dalk net 'n lugspieëling op die gesigseinder, moet die hoop op 'n meer volhoubare toekomstige bedeling nie laat vaar word nie. Die aftakeling van apartheid het bewys dat volgehoue morele druk in die lang termyn 'n wesenlike effek het, selfs waar magsverhoudings baie ongelyk is. Laat die hoop voortleef dat dit op die terrein van volhoubare ontwikkeling ook tot ware vooruitgang vir die planeet en haar mense kan lei.

\section{Geraadpleegde bronne}

ALLEN, R. 1980. How to save the world. Londen: Kogan Page.

ANON. 1995. United Nations Conferences, 1970-1995 - UN Conference on the Human Environment; UN Conference on Environment and Development. Environment, April. http://findarticles.com/p/articles/mi_m1076/is_n3 _v37/ai_16957235 Date of access: 4 Aug. 2007.

ANON. . 2002a. United Nations summit's South African host says trade is no boon to poor. Chicago Tribune: 3, 27 Aug.

ANON. 2002b. World Summit opens. Goal is to end poverty, save natural resources. Chicago Tribune: 4, 26 Aug.

BAKER, S. 2006. Sustainable development. Londen: Routledge.

BASNEY, L. 1994. An earth-careful way of life: Christian stewardship and the environmental crisis. Downers Grove: InterVarsity.

BURGEN, A., MCLAUGHLIN, P. \& MITTELSTRASS, J., eds. 1997. The idea of progress. Berlyn: De Gruyter.

BURY, J.B. 1932. The idea of progress. New York: Dover.

CARSON, R. 1962. The silent spring. London: Hamilton.

CENTER FOR INTERNATIONAL ENVIRONMENTAL LAW. 2007. Human rights, environment, and economic development: existing and emerging standards in international law and global society: overview of existing and emerging legal principles. http://www.ciel.org/Publications/olp3iv.html Date of access: 4 Aug. 2007.

COOMER, J. 1979. Quest for a sustainable society. Oxford: Pergamon.

DODDS, E.R. 1973. The ancient concept of progress. Oxford: Oxford University Press. 
DU PISANI, J.A. 2006. Sustainable development - historical roots of the concept. Environmental sciences, 3(2):83-96.

EDELSTEIN, L. 1967. The idea of progress in classical antiquity. Baltimore: Hopkins.

EHRLICH, P.R. 1968. The population bomb. New York: Ballantine.

FISHER, W.F. \& PONNIAH, T., eds. 2003. Another world is possible: popular alternatives to globalization at the World Social Forum. Nova Scotia: Fernwood.

GLACKEN, C.J. 1967. Traces on the Rhodian Shore: nature and culture in Western thought from ancient times to the end of the eighteenth century. Berkeley: University of California Press.

GOLDSMITH, E. et al. 1972. A blueprint for survival. Harmondsworth: Penguin.

GOUSMETT, C. \& CHIMUKA, A.T. 1997. Responsibility for our natural environment. Potchefstroom: IRS. (Wetenskaplike bydraes van die PU vir $\mathrm{CHO}$, reeks $\mathrm{F}$.)

HORTON, R. 2002. Correct approach to the Earth Summit in Johannesburg. IISD The Times: 20 Aug.

kyk INTERNATIONAL INSTITUTE FOR SUSTAINABLE DEVELOPMENT

INTERNATIONAL INSTITUTE FOR SUSTAINABLE DEVELOPMENT. 1992. A summary of the proceedings of the United Nations conference on environment and development 3-14 June 1992 - Agenda 21, chapter 33: financial resources and mechanisms. Earth negotiations bulletin, 2(13). http://www.iisd.ca/vol02/0213024e.html Date of access: 3 Aug. 2007.

INTERNATIONAL UNION FOR CONSERVATION OF NATURE AND NATURAL RESOURCES. 1980. World conservation strategy: living resource conservation for sustainable development. Gland: IUCN/UNEP/WWF.

INTERNATIONAL UNION FOR CONSERVATION OF NATURE AND NATURAL RESOURCES. 1991. Caring for the earth: a strategy for IUCN sustainable living. Gland: IUCN/UNEP/WWF.

\section{kyk INTERNATIONAL UNION FOR CONSERVATION OF NATURE AND} NATURAL RESOURCES

KENNY, M. 1994. Ecologism. (In Eccleshall, R., ed. Political ideologies: an introduction. Londen: Routledge. p. 218-251.)

MEADOWS, D.H., MEADOWS, D.L., RANDERS, J. \& BEHRENS, W.W. 1972. The limits to growth: a report of the Club of Rome's project on the predicament of mankind. New York: Universe.

NISBET, R. 1980. History of the idea of progress. Londen: Heinemann.

NORTHCOTT, M.S. 1996. The environment and Christian ethics. Cambridge: Cambridge University Press.

PAXTON, L. 1993. Enviro facts 3: sustainable development. Howick: Environmental Education Association of Southern Africa.

PEET, R. 1999. Theories of development. New York: Guilford.

PEPPER, D. 1986. The roots of modern environmentalism. Londen: Routledge.

ROSTOW, W.W. 1978. The world economy: history and prospect. Londen: Macmillan.

SCHUMACHER, E.F. 1973. Small is beautiful: a study of economics as if people mattered. Londen: Blond \& Briggs. 
SEIDMAN, A. \& ANANG, F., eds. 1992. Twenty-first century Africa: towards a new vision of self-sustainable development. Trenton: Africa World Press.

SINGHAL, P.K. \& SHIVASTAVA, P., eds. 2004. Challenges in sustainable development. New Delhi: Anmol.

SO, A.Y. 1990. Social change and development; modernization, dependency and world-system theories. Londen: Sage.

STRACHAN, J.R., AYRE, G., McHARRY, J. \& CALLWAY, R. 2005. The plain language guide to the World Summit on sustainable development. Londen: Earthscan.

UN

UNCHE

kyk UNITED NATIONS

kyk UNITED NATIONS CONFERENCE ON THE HUMAN ENVIRONUNDP MENT

UNEP

kyk UNITED NATIONS DEVELOPMENT PROGRAMME

UNGA

kyk UNITED NATIONS ENVIRONMENTAL PROGRAMME

kyk UNITED NATIONS GENERAL ASSEMBLY

UNITED NATIONS. Department of Economic and Social Affairs. Division for Sustainable Development. 1992a. Agenda 21. http://www.un.org/esa/ sustdev/documents/agenda21/english/agenda21toc.htm Date of access: 25 May 2007.

UNITED NATIONS. Department of Economic and Social Affairs. Division for Sustainable Development. 1992b. Report of the United Nations Conference on Environment and Development (Rio de Janeiro, 3-14 June 1992), document no. A/CONF.151/26, vol. 1. Annex 1: Rio Declaration on Environment and Development. New York: United Nations General Assembly.

UNITED NATIONS. Department of Economic and Social Affairs. Division for Sustainable Development. 2002. Johannesburg Declaration on Sustainable Development, 2002. http://www.un.org/esa/sustdev/ documents/ WSSD_POI_PD/English/POI_PD.htm Date of access: 5 Aug. 2007.

UNITED NATTIONS. Economic and Social Council. 1996. Combating poverty. Report of the Secretary-General, Commission on Sustainable Development (CSD), Fourth session, 18 April-3 May, ESC E/CN.17/1996/9.

UNITED NATIONS. Economic and Social Council. 1997. Overall progress achieved since the United Nations Conference on Environment and Development. Report of the Secretary-General, Addendum: Combating poverty, Commission on Sustainable Development (CSD), Fifth session, 725 April, ESC E/CN.17/1997/2/Add.2.

UNITED NATIONS DEVELOPMENT PROGRAMME. 2007. About the MDGs: Basics. http://www.undp.org/mdg/basics.shtml Date of access: 4 Aug. 2007.

UNITED NATIONS ENVIRONMENTAL PROGRAMME. 2001. African Ministerial Statement to the World Summit on Sustainable Development adopted at the African Preparatory Conference for the World Summit on Sustainable Development, held in Nairobi from 15 to 18 October 2001. http://www. unep.org Date of access: 30 May 2007. 
UNITED NATIONS ENVIRONMENTAL PROGRAMME. 2007a. Declaration of the United Nations Conference on the Human Environment, 16 June 1972. http://www.unep.org/Documents. Multilingual/Default.asp?DocumentID=97 \&ArticleID=1503 Date of access: 24 Aug. 2007.

UNITED NATIONS ENVIRONMENTAL PROGRAMME. 2007b. Stockholm 1972: brief summary of the general debate. http://www.unep.org/ Documents.Multilingual/Default.asp?DocumentID=97\&ArticleID=1497 \&1=en Date of access: 25 May 2007.

UNITED NATIONS GENERAL ASSEMBLY. 1983. Resolutions adopted by the General Assembly at its 38th session, 1983, A/RES/38/161, 131-132: Resolution 38/161 "Process of preparation of the environmental perspective to the year 2000 and beyond", adopted by the General Assembly at its 102nd plenary meeting, 19 December 1983. http://daccessdds.un.org/doc/RESOLUTION/GEN/NR0/445/53/IMG/NR04 4553.pdf?OpenElement Date of access: 3 Aug. 2007.

UNITED NATIONS GENERAL ASSEMBLY. 1987. A/42/427, Report of the World Commission on Environment and Development ("Our Common Future"), 4 August 1987, Annexe 2: The Commission and its Work, 34351. http://daccessdds.un.org/doc/UNDOC/GEN/N87/184/67//MG/ N8718467pdf?OpenElement Date of access: 3 Aug. 2007.

VAN DYKE, F. 1996. Redeeming creation: the Biblical basis for environmental stewardship. Downers Grove: InterVarsity.

VAN ZON, H. 2002. Geschiedenis \& duurzame ontwikkeling: duurzame ontwikkeling in historisch perspectief. Nijmegen: Werkgroep Disciplinaire Verdieping Duurzame Ontwikkeling.

VIEDERMANN, S. 1993. Sustainable development: what is it and how do we get there? Current history, 92(573):181.

VORSTER, W.S., ed. 1987. Are we killing God's earth?: ecology and theology. Pretoria : University of South Africa. (Institute for Theological Research.)

VOS, C.J.A. \& Muller, J.C., reds. 1991. Mens en omgewing. Halfway House: Orion.

WACKERNAGEL, M. \& REES, W.E. 1996. Our ecological footprint: reducing human impact on the earth. Gabriola Island: New Society.

WEBER, M. 1990. The Protestant ethic and the spirit of capitalism. 1930 ed. transl. by Talcott Parsons. London: Hyman.

WHITE, L. 1967. The historical roots of our ecologic crisis. Science, 155(3767): 1203-1207.

WILKINSON, L., ed. 1980. Earthkeeping: Christian stewardship of natural resources. Grand Rapids: Eerdmans.

WILKINSON, L., ed. 1991. Earthkeeping in the nineties: stewardship of creation. Revised ed. Grand Rapids: Eerdmans.

WORLD BANK. 2004. Beyond economic growth. Washington D.C: World Bank. http://www.worldbank.org/depweb/english/beyond/beyondco/beg_04.pdf Date of access: 25 May 2007.

WORSTER, D. 1993. The wealth of nature: environmental history and the ecological imagination. New York: Oxford University Press.

YELD, J. 1997. Caring for the earth South Africa. Stellenbosch: WWF.

YOUNG, J. 1990. Post environmentalism. Londen: Bellhaven.

YOUNG, R.A. 1994. Healing the earth: a theocentric perspective on environmental problems and their solutions. Nashville: Broadman \& Holman. 


\section{Kernbegrippe:}

armoedeverligting omgewingsbewaring volhoubare ontwikkeling

\section{Key concepts:}

environmental conservation poverty alleviation

sustainable development 